\title{
Defining Psychiatry: Aubrey Lewis's 1938 Report and the Rockefeller Foundation
}

\author{
KATHERINE ANGEL
}

\section{Introduction}

Aubrey Lewis finished his report on psychiatry in Europe in 1938, having travelled to centres of psychiatry and allied fields on the Continent between March and September 1937. He had been at the Maudsley Hospital for nine years, with five years as a consultant and one as clinical director. While Lewis stated that the aim of the trip to the Continent was "to learn what is being done in neuropsychiatry and related fields", saying that it was "at the suggestion and with the support of the Rockefeller Foundation", it is worth dwelling on the question of the wider aims it may have served.

The trip can be located in the context of Edward Mapother's desire to create an outstanding institution which would foster research, raise teaching and training standards, and thereby raise the quality and status of psychiatry in England. ${ }^{2}$ Mapother, keen to groom individuals who would pursue the same goals of institutional, disciplinary and scientific excellence which he admired in American psychiatry, and having Lewis in

Katherine Angel, MA, MPhil. (Cantab), Department of History and Philosophy of Science, Cambridge University, Free School Lane, Cambridge CB2 3RH.

This paper has come out of research I undertook while Research Assistant to Michael Neve and Edgar Jones. I would like to thank Professor Hal Cook and Alan Shiel at the Wellcome Trust Centre for the History of Medicine at University College London for encouraging me to visit both the Institute for the History of Science and Medicine at the University of Lübeck and the Rockefeller Archive Centre in Sleepy Hollow, New York. Thanks are also due to Thomas Rosenbaum and Dr Erwin Levold at the Rockefeller Archive Center; Dr Naomi Cream for providing valuable background material; and Professor John Forrester for helpful comments on the earlier drafts of my essay. Warm thanks in particular to Michael Neve for insightful discussion throughout.

\footnotetext{
${ }^{1}$ Bethlem Royal Hospital Archives, C/12/3, Aubrey Lewis Box 9, p. 1.

${ }^{2} \mathrm{~A}$ refashioning of the notion of Englishness in the late nineteenth and early twentieth centuries was a key element in negotiating concepts of liberalism, democracy and civilisation. According to Robert Colls and Philip Dodd, the new cultural understanding of "Englishness" was crucial to the stabilisation of British life; a significant factor in the dominant version of Englishness in the last two decades of the nineteenth century and the early years of the twentieth century was its ability to represent itself to others and others to themselves; so Englishness also defined the Scottish, the Welsh and the Irish. While at one level it would seem that Lewis uses the term "English" to denote psychiatry in England, it is worth thinking about the ways in which usage of this term might embody certain debates about the concept of Englishness. See Christopher Lawrence and Anna-K Mayer, 'Regenerating England: an introduction', in idem (eds), Regenerating England: science, medicine and culture in inter-war Britain, Clio Medica 60, Amsterdam, Rodopi, 2000, pp. 5-9. See also Robert Colls and Philip Dodds (eds), Englishness: politics and culture 1880-1920, London, Croom Helm, 1986.
} 


\section{Katherine Angel}

mind as his potential successor, ${ }^{3}$ may have perceived the trip as a means for Lewis to gain the knowledge of techniques, new developments and theoretical perspectives in other countries that Mapother felt was necessary for such a position. ${ }^{4}$

What complicates the reading of Lewis's tour as a means to acquire the expertise of seasoned institutions (expertise in research and clinical methods as well as in the organisation of institutions) is the wealth of negative impressions he records from his visits $^{5}$ - a fact made more interesting by the negotiations that Mapother was holding with the Rockefeller Foundation on possible increased financial support for the Maudsley. When in June 1930, Alan Gregg, director of the Rockefeller Foundation's Medical Services Division, first visited the Maudsley Hospital and Mapother, he said that he could not undertake a commitment regarding funding until he had visited similar institutions in England and on the Continent. ${ }^{6}$ Mapother must have felt keenly the negative comparison the Maudsley might suffer with other European institutions. At the time of Lewis's trip, psychiatry in Europe was not a coherent or unified enterprise, nor was there agreement over uncomplicatedly successful therapeutics, or a persuasive theoretical framework intersecting with therapies. Several countries, however - most obviously Switzerland, Austria and France ${ }^{7}$ - boasted individuals in prestigious institutions producing significant findings, as well as people practising the relatively young but increasingly influential psychoanalysis, the relation of which to psychiatry was not yet clear. These features of European psychiatry must have highlighted only too sharply the relative inertia of the field in England.

While in 1934 and 1935 the Rockefeller funded three German émigrés at the Maudsley, and in 1935 awarded the hospital $£ 9,000$ over three years, with in 1938 a further $£ 5,000$ per year for five years, Mapother had initially asked for more substantial sums from the Foundation, which had dragged its feet. ${ }^{8}$ While in his introduction Lewis acknowledges the superior training and experience in research in continental institutions, he emphasises the increasing renown of the Maudsley, and claims that England and the USA are supplanting Germany in medical and psychiatric progress. ${ }^{9}$ Although he invokes political reasons for the demise of German psychiatry, he does seem to

\footnotetext{
${ }^{3}$ Mapother had admired the "medical spirit dominating psychiatry" when he visited America. Edward Mapother, 'Impressions of psychiatry in America', Lancet, 1930, i: 848.

${ }^{4}$ Mapother, writing to Alan Gregg, described Lewis's trip as "just the sort of thing he needs to fit him to take over the lead of the teaching side from me presently", adding that "he will be of very real advantage for the future of the hospital". Mapother to Gregg, 12 December 1936, series 401A, Record Group (RG) 1.1, Rockefeller Foundation Archive (hereafter RFA), Rockefeller Archive Center (hereafter RAC), Sleepy Hollow, New York. Rockefeller documents recording Lewis's fellowships state that the 1937 trip was felt to "be of particular importance to L. and to his colleagues in London, and will bring about greater familiarity with work in other countries and a better correlation of research activities. Because of L's qualifications and critical abilities, his trip should be of unusual profit; and the full reports which he consented to write on his visits should be of value to the Paris Office". Fellowship cards, RG 10, series MS Great Britain, RFA, RAC.

${ }^{5}$ See Report, especially the concluding 'General Impressions', pp. 143-7.

${ }^{6}$ Alan Gregg officer's diary, 11 June 1930, RG 12.1, RFA, RAC.

${ }^{7}$ The political situation in Germany made a journey there fraught with difficulties (as was a trip to civil war-torn Spain). Lewis was therefore unable to visit the country where successfully institutionalised, scientific and research-based medicine and psychiatry had originated and excelled until the 1930s.

${ }^{8}$ The significance of the presence of the German émigrés is addressed in the conclusion. See also Edgar Jones's essay, p. 18.

${ }^{9}$ See Introduction to the Report, p. 57.
} 


\section{Defining Psychiatry}

want this claim to signify something positive about English psychiatry per se. While Lewis was sent to the Continent to gain the perspectives and knowledge that would help to make the Maudsley a more impressive candidate for Rockefeller patronage, ${ }^{10}$ his disappointments and criticisms perhaps indicate a desire on his part, and possibly that of Mapother, to take continental psychiatry down a peg or two and dispel what certainly Lewis deemed was a myth of excellence. Of course, it may simply be that Lewis's criticisms reflect the character traits which later led to his reputation as someone who spoke the truth, regardless of the views of others or the inconvenience it might cause. ${ }^{11}$

In this essay I propose to study Lewis's report with the presence of the Rockefeller Foundation in mind. I shall first consider briefly the state of psychiatry in Europe at the time, and then look at American psychiatry. Common to both was a desire to make psychiatry a scientific discipline on a par with the rest of medicine, with all the trappings and the connotations that such an achievement would confer. Within this context I shall consider the engagement of the Rockefeller with the question of what psychiatry was - what it included, and therefore what its status was. Worries about this still rather inchoate field were foremost in the thinking of the Rockefeller, forming a crucial backdrop both to Lewis's trip to the Continent and to the question of Maudsley funding. To the extent that Lewis's trip was heavily influenced, if not designed, by the Rockefeller, that Lewis echoed the Rockefeller's feelings regarding the boundaries of a respectable, scientific psychiatry, and that the Rockefeller played a crucial role in the development of the Maudsley Hospital and therefore of English psychiatry, such a consideration of the dynamics between the Foundation and Lewis's early career is instructive. Although a thorough examination of the question lies beyond the scope of this essay, it is clear that Rockefeller influence was of great importance to his career in, and ideas about, psychiatry, especially given the extent to which these would shape English post-war psychiatry.

\section{A Note on Terminology}

The term "psychiatry" is useful but potentially misleading. What would gradually become psychiatry over the course of the first few decades of the twentieth century was, at the time of Lewis's trip, still a fragmented domain of mental health, which embraced asylum-based doctors (aliénistes), private-practice neurologists, general practitioners, and, increasingly, psychoanalysts. Although the term "psychiatry" was widely used in the thirties, its meaning was slippery. By the turn of the twentieth

\footnotetext{
${ }^{10}$ While the Rockefeller Foundation aimed to fund institutions in need of help, it also had a long-standing policy of "building on strength rather than on weakness". Raymond B Fosdick, The story of the Rockefeller Foundation, London, Odhams Press, 1952, p. 119.

${ }^{11}$ It is not clear from the sources available what happened to Lewis's report; we know that the Rockefeller Foundation read it and found it useful, but not whether they read a more official version than the one we have here, or what the reaction to some of its quite critical content may have been. O'Brien wrote to Gregg on the possibility of a visit to the US by Mapother that "[w]hat I had in mind was something analogous to the survey made by Aubrey Lewis in Europe, which I found useful." O'Brien to Gregg, 11 March 1939, RG 1.1, series 401A, folder 256, box 19, RFA, RAC. Gregg replied that the "difference between Mapother's visit to the United States and the survey made by Aubrey Lewis in Europe lies more in the usefulness of such a visit to the future than in its immediate value to us." Gregg to O'Brien, 30 March 1939, RG 1.1, series $401 \mathrm{~A}$, folder 256 box 19, RFA, RAC.
} 


\section{Katherine Angel}

century, psychiatry's status was problematic (given the overcrowded asylums), and the increasing (and increasingly laboratory-based) focus in the nineteenth century on the brain as underlying mental illness, along with the practice of casting psychiatric illness as "nervous illness", 12 had led to a situation where the distinctions between psychiatry and neurology were by no means clear. ${ }^{13}$ While in the early twentieth century in Britain and America psychiatrists were still mostly asylum-based, with "nerve specialists" becoming part of general medicine's élite, in central Europe psychiatry and neurology were kept together. Thus many of Lewis's contemporaries on the Continent were professors of mental and nervous diseases, or of psychiatry and neurology, terminology which reflects the legacy of (mostly German) nineteenth-century biological and anatomical psychiatry.

\section{Psychiatry in the 1930s}

As Edgar Jones indicates in his essay, psychiatry in Britain was highly fragmented in the interwar period; it remained in the asylums virtually until the Second World War, and there were almost no laboratories or research institutes. The Maudsley was to fill a real gap, and its creation was part of a larger trend that had been unfolding in psychiatry: the foundation of institutions often linked to universities, with clinics providing the link between laboratory science and clinical practice.

-More generally, psychiatry in Western Europe in the first decades of the twentieth century had seen the nineteenth century's biological and anatomical focus wane. Despite the rise of neurology, and eminent figures such as Pavlov, Alzheimer, Pick and Sherrington doing lasting neuropathological work, what would come to be called "brain mythology" had yielded relatively little in terms of concrete aetiological, diagnostic and therapeutic findings. And although popular forms of treatment included rest and diet cures, barbiturates, baths, massages and surgery in cases of focal sepsis, there was little consensus about how they worked and no unifying framework for them.

By the beginning of the century in many European countries (even before any consistent dissemination of Freud's ideas), psychodynamic approaches and an already robust notion of the unconscious were fairly widely used by figures such as Eugen Bleuler and Auguste-Henri Forel in their theoretical and clinical work. By the 1930s, psychoanalysis had a significant presence in Europe. However, there was no compulsion to

\footnotetext{
${ }^{12}$ Edward Shorter argues that the association of psychiatry with degeneration and insanity led to an endorsement of notions of "nervous illness", which both fostered office-based "neurology" and reassured patients fearful of psychiatry's implications. Edward Shorter, History of psychiatry: from the era of the asylum to the age of Prozac, New York, John Wiley, 1997, pp. 113-44. "Psychiatrists" were originally alienists, based in asylums, while "neurologists" were originally trained in pathology and internal medicine; the latter, however, had come under pressure to focus on psychoneuroses in addition to their primary interest in neurological implications of all sorts of disease. Neurologists thus became office-based practitioners of psychotherapy, catering to the middle- and upper-classes; such comforts would play a role in the later move towards psychotherapy and psychoanalysis amongst psychiatrists.

${ }^{13}$ As Shorter writes of the ultimately unsuccessful laboratory-focused psychiatry at the end of the nineteenth century, "What Nissl and Alzheimer could find under their microscopes they declared 'neurology'. What they couldn't find was psychiatry." (Shorter, op. cit., note 12 above, p. 109.) Nissl himself wrote that without clarification of the relationships between brain anatomy and brain function, the search for relationships between the findings of brain anatomy and psychiatric findings was difficult and ultimately pointless. (Franz Nissl, 'Über die Entwicklung der Psychiatrie in den letzten 50 Jahren', Verhandlungen des Naturhistorisch-Medizinischen Vereins, 1908, N.F. 8: pp. 510-25.)
} 


\section{Defining Psychiatry}

choose between it and organic, or biological, psychiatry; many practitioners, such as Max Müller in Switzerland - as Lewis notes with interest - fostered analysis as well as the new physical treatments. Psychoanalysis and psychotherapy received renewed scrutiny and respect after the First World War, and became increasingly attractive to psychiatrists eager to have an office-based specialty. By the 1920s both these fields had begun to have a strong presence in continental universities and education generally, influencing a growing number of disciplines. To the hysterical and neurotic disorders under the gaze of psychoanalysis had been added problems such as schizophrenia, although this widening of the remit of analysis led to debate within the movement which partly contributed to various splits. By the time of Lewis's visit, however, the future presence of psychoanalysis in the UK, and its pre-eminence in the US, had been guaranteed by the emigration of several key analysts.

While the biological thinking of the nineteenth century had begun to disintegrate, psychiatry, in the fifteen years or so before Lewis's trip, had stumbled upon some highly organic interventions, largely unconnected to particular theoretical frameworks, which raised new hopes of therapeutic success. These discoveries, however, yielded multiple complications, and failed to deliver their initial promise of dramatic cure. So while Wagner-Jauregg's fever therapy for neurosyphilitic psychosis had been producing results from the early twentieth century, and brought the therapeutic nihilism often attributed to the epoch to an abrupt halt, it turned out to be highly dangerous. ${ }^{14}$ Moreover, neurosyphilis had a distinctive and specific cause; other causes of major mental illness (the "functional" psychoses such as schizophrenia, or manic-depressive illness), were, however, of unknown aetiology, which made searching for treatments far less successful.

Jakob Klaesi's prolonged narcosis to treat psychosis was widely adopted in the twenties, but it too turned out to be dangerous. In 1927 Max Müller exposed the death rate associated with Somnifen, ${ }^{15}$ the drug Klaesi used (the technique was later modified with other drugs).$^{16}$ At the time of Lewis's trip, Manfred Sakel's publications on insulin coma therapy were very recent, ${ }^{17}$ and, despite enthusiasm for the treatment,

\footnotetext{
${ }^{14}$ Paul Ehrlich's proposals in 1910 to use Salvarsan for neurosyphilis had also seemed promising, but in order to be effective the compound had to be administered early, and, by the time symptoms were clinically evident, it was often too late.

${ }^{15}$ Max Müller, 'Die Dauernarkose mit flüssigem Dial bei Psychosen, speziell bei manisch-depressivem Irresein', Zeitschrift für die gesamte Neurologie und Psychiatrie, 1927, 107: 522-43.

${ }^{16}$ Klaesi saw the use of prolonged narcosis as a means of making patients more accessible to psychotherapy - not necessarily to effect an outright cure by physical means. It was used in this way for quite some time.

${ }^{17}$ Manfred Sakel published his initial findings on the beneficial effects that inadvertently going into an insulin coma had on the restlessness and agitation of morphine addicts in 'Neue Behandlung der Morphinsucht', Zeitschrift für die gesamte Neurologie und Psychiatrie, 1933, 143: 506-34, and then the results of the application of this finding to schizophrenia in a 13-part series, 'Schizophreniebehandlung mittles Insulin-Hypoglykämie sowie hypoglykämischer Shocks', Wiener Medizinische Wochenschrift, 3 November 1934, 84: 1211-13, to 9 February 1935, 85: 179-80. Lewis, in his Report (p. 85), writes that Steck in Lausanne had suggested this use of insulin previously, and it seems that Sakel was unaware of previous attempts to use it as a treatment for psychosis. (See F E James, 'Insulin treatment in psychiatry', Hist. Psychiatry, 1992, 3: 221-35.)
} 


\section{Katherine Angel}

it was soon shown to be equally beset by complications. ${ }^{18} 1935$ saw the publication of Ladislas von Meduna's experiments with camphor-induced convulsions on psychosis, and later with cardiazol; but these were unreliable and produced too great anxiety and pain in patients. ${ }^{19}$ Lewis refers in his report to the risks of insulin and cardiazol use, distinguishing immediate from long-term outcome, and noting that much depends on what is meant by "good results" of insulin. ${ }^{20}$ Recovery without insight, he says, is "a dubious kind of recovery", ${ }^{21}$ and he is critical of Ugo Cerletti's claims regarding "cured" patients. 22

At the time, these were exciting breakthroughs in the treatment of psychiatric illness. But, although they provoRed results undreamed of thirty years previously, it soon became clear they were primarily useful in sedating agitated patients, rather than curing them. Moreover, psychiatrists struggled with the problems they raised, lacking in systematic theoretical understanding of the phenomena with which they were confronted. These discoveries appeared while psychiatry was on the cusp of the new hope that electroshock therapy would offer, as well as a few years away from the successful use of penicillin in primary syphilis. These new beacons of light for intractable conditions seemed merely to highlight the frustrating aetiological and therapeutic quandaries besetting the field.

Psychiatry was thus unsettled, exciting and perplexing, with representatives from its various specialties tussling to define its nature. It seemed to many, however, that great success could be found within it, if only an institutional and scientific context for it could be fostered. Mapother's project at the Maudsley Hospital was part of such a process, and Lewis and the Rockefeller Foundation, both so crucial to the Maudsley's development, were subject to the puzzles and anxieties which went hand in hand with such a task.

\section{Political Contexts}

One cannot think of Europe in 1937 without a grim awareness of the very recent developments preventing Lewis from visiting the very country whose institutions were the prototype for Mapother's project, as well as for most psychiatric institutions in Europe and the United States in the early twentieth century. Germany's position in psychiatry was pre-eminent until 1933, but by 1937 the field had been unrecognisably altered by political incursions. The Law for the Prevention of Offspring with Hereditary Diseases, enforcing compulsory sterilisation, was introduced only a few months after Hitler seized power in 1933. Many of the diseases considered hereditary - schizophrenia, cyclothymia, hereditary epilepsy, Huntington's chorea, severe

\footnotetext{
${ }^{18}$ Although it soon became clear that real cure was not achieved, temporary improvement and the comparative gentleness of insulin therapy ensured that it was still used in many countries until relatively recently.

${ }^{19}$ Cardiazol was none the less widely used, especially in the United States until the end of the 1940s.

${ }^{20}$ The quote is in the report, p. 89. Lewis discusses the issues also on pp. 85-6, 89-90.

${ }^{21}$ Report, p. 89.

${ }^{22}$ Report, page 101. See also pp. 108-9 where Lewis records scepticism about Sakel's insulin treatment and Otto Pötzl's involvement in Sakel's work. Shorter writes that "beyond the university clinic, Sakel's results were considered a joke, the man himself a charlatan, and Pötzl's patronage of him a mystery." Shorter, op. cit., note 12 above, p. 210.
} 


\section{Defining Psychiatry}

alcoholism, and congenital mental deficiency - fell under psychiatry's remit. The killing of psychiatric patients had been planned since 1935 at least, and was to be undertaken in earnest in 1939, when Nazism revealed the full brutality of its psychiatric and medical programmes.

The Soviet Union was also beginning to hold psychiatry hostage to politics. Stalin's extraordinary repressive purges had been going on in earnest from 1936, although the Academy of Sciences of the USSR, like many other organisations, had been a target of purges from as early as $1929 .{ }^{23}$ Transferred in 1934 from Leningrad to Moscow and made directly subordinate to the government, the Academy of Sciences was merged in 1936 with the Communist Academy in order to increase its political orientation. It became at this time the most important scientific institution in the nation. ${ }^{24}$ All of the thirteen successive secretaries of the Kiev Academy of Sciences between 1921 and 1938 were arrested, ${ }^{25}$ and Sidney Bloch and Peter Reddaway state that between 1936 and 1938 Andrei Vyshinsky, subordinate of the head of secret police, initiated the confinement of dissenters in prison psychiatric hospitals. ${ }^{26}$ Robert Conquest estimates that between 1933 and 1935, 5 million people were imprisoned in labour camps, and this number rose slightly between 1935 and $1937 .{ }^{27}$ Whether Lewis would have been aware of these particular developments at the time of his trip is unclear; he certainly seems frustrated in Russia by the grandiose (and he thinks false) claims made for Russian psychiatric work, as well as by the impenetrability of institutions and individuals. He may well have been unaware of the magnitude of the pressures on, and potential risk to, the individuals he met. ${ }^{28}$

\section{The Rockefeller Foundation and Psychiatry}

The 1930s saw the Rockefeller Foundation injecting significant funds into scientific research in, and the institutional organisation of, psychiatry, in much the same way that it had previously done in medicine. ${ }^{29}$ In 1933 in the United States, "teaching

\footnotetext{
${ }^{23}$ Zhores A Medvedev, Soviet science, New York, W W Norton, 1978, p. 27.

${ }^{24}$ Ibid., p. 38.

${ }^{25}$ Robert Conquest, The great terror: a reassessment, London, Hutchinson, 1990, p. 293.

${ }^{26}$ Sidney Bloch and Peter Reddaway, 'Psychiatrists and dissenters in the Soviet Union', in Eric Stover and,Elena $\mathrm{O}$ Nightingale (eds), The breaking of bodies and minds: torture, psychiatric abuse and the health professions, New York, W H Freeman, 1985, pp. 132-63, on p. 133. Bloch and Reddaway state that the little evidence there is suggests that the policy of systematically interning dissenters in mental hospitals began during Stalin's rule in the late 1930s. (Ibid., p. 133.)

${ }^{27}$ Conquest, op. cit., note 25 above, p. 311.

${ }^{28}$ His introduction, which appears to have been written after the trip, reveals a greater awareness of the political repression at work. He mentions Italy as well as the Soviet Union (Introduction to the Report, pp. 57-8, 60); for details on the Italian situation, see the Italy section in the report.

${ }^{29}$ It was only relatively recently that medicine had attained scientific status, with the laboratory as a defining component in that status. Again, the models for this were mostly German institutes. The role of the Rockefeller in encouraging the scientisation of medicine stemmed from the joint initiative of John D Rockefeller Sr and Frederick T Gates, principal adviser in business and philanthropy to Rockefeller. The story goes that Gates was impressed with the retarded development of American medicine as he read about it in W Osler's Principles and practice of medicine, and he and Rockefeller put in motion their plans to foster scientific inquiry and medical research. This led to the creation, between 1901 and 1913, of the Rockefeller Institute of Medical Research, the General Education Board, the Rockefeller Sanitary Commission, and the Rockefeller Foundation. See Fosdick, op. cit., note 10 above, pp. 16-28. For a non-insider view of the strategies and philosophies of the Rockefeller, see Ilana Löwy and Patrick Zylberman, 'Medicine as
} 


\section{Katherine Angel}

in psychiatry was poor, research fragmentary, application feeble", the presence of psychology and neurology departments in medical schools was sporadic, and those that did exist were isolated and badly integrated with their neighbouring disciplines. ${ }^{30}$ The practice of psychiatry was often still largely custodial, in unwieldy mental hospitals. Dr David L Edsall, Dean of the Harvard Medical School and a trustee of the Rockefeller Foundation, wrote a report in 1930 on the state of psychiatry which helped to launch the new Rockefeller psychiatry programme. In it he commented, "[p]sychiatry has been distinctly separated from general medical interests and thought, to such a degree that, to very many medical men, it seems a wholly distinct thing with which they have little relation". 31

Adolf Meyer became professor at the new psychiatric unit of the Johns Hopkins Medical School in 1908, where he developed a university psychiatric research and teaching hospital of the kind it was felt the United States needed, and upon which later schools were based. He played a key role in establishing university training for psychiatrists and fostering a more integrated relationship between mental institutions and the growing university medical schools and hospitals. ${ }^{32}$ In so doing, he helped to create a new professional role for psychiatrists, one which would ensure membership of the scientific and medical establishment. These changes in the organisation of a previously splintered field brought together the interests of the aliénistes, trying to shake off the negative associations still conjured up by the asylum, and the neurologists and the internists in the laboratory and the clinic, all of whom were seeking renewed medical authority in the shape of a bona fide, unified professional structure. ${ }^{33}$ Meyer's psychobiology, with its concepts of maladaptation - not a structural defect of mind or body but rather the lowering of a person's ability to function - both increased the client base for psychiatry and potentially afforded different kinds of practitioners equal legitimacy in a pragmatic approach towards environmentally mediated conditions.

This new drive to place psychiatry on a par with scientific medicine was accompanied by a more general change in society's conception of mental illness and psychiatry, especially after the First World War. ${ }^{34}$ These movements are reflected in a changing orientation within the Rockefeller Foundation which had, in the early 1920s, focused on medicine in relation to university teaching, steering clear of basic research. ${ }^{35}$ It had

a social instrument: the Rockefeller Foundation, 1913-1945', in Studies in the History and Philosophy of Biological and Biomedical Sciences (Special Issue: The Rockefeller Foundation and Biomedical Sciences) September 2000, 31c (3): 365-79.

${ }^{30}$ Fosdick, op. cit., note 10 above, p. 148.

${ }^{31}$ David L Edsall, 'Memorandum regarding possible psychiatric developments', 3 October 1930, Rockefeller Foundation, cited in Fosdick, op. cit., note 10 above, p. 147.

32 Theodore Lidz, 'Adolf Meyer and the development of American psychiatry', Am. J. Psychiatry, 1966, 123: 320-32; Mathew Thomson, 'Mental hygiene as an international movement', in Paul Weindling (ed.), International health organisations and movements, 1918-1939, Cambridge University Press, 1995. pp. 283-305; Theodore M Brown, 'Alan Gregg and the Rockefeller Foundation's support of Franz Alexander's psychosomatic research', Bull. Hist. Med., 1987, 61: 155-82; Jack Pressman, Last resort: psychosurgery and the limits of medicine, Cambridge University Press, pp. 18-47.

${ }^{33}$ The concern besetting the diffuse field of mental illness in the first decades of the twentieth century was precisely that of whether, and how, to contain within one speciality practices as diverse as asylum psychiatry, neurology, neuropathology, brain anatomy, psychology, and psychotherapy.

${ }^{34}$ See Pressman, op. cit., note 32 above, pp. 18-30, for details on the initiatives of the National Committee for Mental Hygiene chief medical officer Thomas Salmon.

${ }^{35}$ Fosdick, op. cit., note 10 above, p. 142. 


\section{Defining Psychiatry}

had little involvement with psychiatry, although during his directorship of the Division of Medical Education (1919-1930), Richard M Pearce had ruminated on a possible new programme in psychiatry, and taken an interest in Emil Kraepelin's Institute in Munich, the Kaiser Wilhelm Institute for Brain Research in Berlin, and the Pasteur Institute at the College de France in Paris. ${ }^{36}$ In 1929 the Rockefeller Foundation was reorganised, and the Division of Medical Education became the Division of Medical Sciences, reflecting a new policy of extending knowledge through support of scientific research, and eventually with a new focus on psychiatry, encouraged by Pearce's successor Alan Gregg. ${ }^{37}$

When Gregg succeeded Pearce in 1930, he had to persuade the Foundation, presided over by the sceptical Max Mason, a former physicist, of the wisdom of a significant endorsement of psychiatry. Edsall's memorandum in 1930 had articulated the worries of many in the Rockefeller: he described psychiatry as a "field dominated by elusive and inexact methods of study and speculative thought"; he urged cautious investigation via exclusive pursuit of "real scientific studies" in "forcible laboratories or institutes, prepared to study such matters related to psychiatry as are subject to attack by the methods of more or less exact sciences". He urged that psychoanalysis should be bypassed because it could not at that time be "accurately studied from a scientific viewpoint". ${ }^{38}$ In a discussion in 1930 of a possible psychiatry programme, there was uncertainty as to the methods psychiatry should employ, and as to its fit within a scientific medicine: a representative comment was that the subject "requires fresh thinking; the experimental method of medicine does not apply; there must be new techniques". ${ }^{39}$ In the same discussion, Edsall is recorded as contrasting the changes which had come about in thirty years in medicine - through physiology and nutritional studies - with the state of psychiatry, in which practitioners "have not produced the kind of advance upon which to build". ${ }^{40}$ While the Rockefeller's mission was to "improve the well-being of mankind", and its activities were not confined to pure science, it was a dogged advocate of the merits of science, especially within medicine, and was highly preoccupied by the risk of undertaking projects which might undermine this ideal.

In April 1933 the Trustees agreed to "the plans of the Division of Medical Sciences to concentrate on psychiatry", ${ }^{41}$ the justification being that psychiatry was one of the most backward, but "also one of the most probably fruitful", ${ }^{2}$ fields. A sense of optimism with regard to medicine also fostered a growing involvement in psychiatry: "With increasing control over organic diseases, functional diseases will more and more be

\footnotetext{
${ }^{36}$ Ibid., p. 142.

${ }^{37}$ Mathew Thomson writes that the Rockefeller Foundation's failure to make progress in the field of mental hygiene, which it had supported between 1919 and 1939, may have encouraged the Foundation to concentrate on a more scientific approach (op. cit., note 32 above, p. 290).

${ }^{38}$ David Edsall, 'Memorandum regarding possible psychiatric developments', 3 October 1930, RG 3, series 906, folder 19, box 2, RFA, RAC.

${ }^{39}$ Excerpt from Rockefeller Foundation Conference Report, 12 October 1930, RG 3, series 906, folder 19 , box 2, RFA, RAC.

40 Ibid.

${ }^{41}$ Report of Appraisal Committee, 11 December 1934, RG 3, series 906, folder 19, box 2, RFA, RAC.

${ }^{42}$ Excerpt from the Agenda for Rockefeller Foundation meeting, 11 April 1933, RG 3, series 906, folder 19 , box 2, RFA, RAC.
} 


\section{Katherine Angel}

presented as the problem", a member in a staff conference claimed. ${ }^{43}$ (Gregg, in 1941 , praising the advances in medicine from 1880 , also wrote that "there has been, for the past fifty years, however, something approaching neglect of the patient as a person". ${ }^{44}$ ) The annual report for 1934 argued that, in addition to research and maintenance grants to help train already established men, able persons had to be found, trained and allowed to conduct research in psychiatry through scholarships, fellowships and decently-paid posts. The best young talent would then be attracted to a solid and eminent field. ${ }^{45}$

Thus the number of projects funded by the Medical Science Division under the Psychiatry Program of Specific Concentration in 1934 rose from a modest four in 1933 (costing $\$ 234,900$ ) to eleven (costing $\$ 255,000$ ), with another $\$ 49,100$ spent on five projects in neurology and $\$ 45,900$ spent on other medical fields. ${ }^{46}$ Until the war at least, money from the Medical Sciences Division went primarily to psychiatry. ${ }^{47}$ The director's Report on the Program in Psychiatry in 1935 states that “[p]sychiatry here comprises clinical psychiatry; clinical neurology; the anatomy, physiology, chemistry, pharmacology and pathology of the nervous system; some phases of psychology; and those phases of other branches of medicine which bear directly on the understanding of human behaviour". ${ }^{48}$ While the range of subjects encouraged were sometimes oddly diverse - neurosurgery alongside anthropometric studies of handwriting, for instance $^{49}$ - there was from the outset, and increasingly, a heavy emphasis placed on those fields of endeavour which were physical and laboratory-based; or at least experimentally-based. The annual report of 1936 urges that a factual foundation be found "for what is often called psychobiology". 50 The aim was a psychiatry whose methods and tools resembled most closely the medicine which had flowered in the previous half-century or so, with pathology, anatomy and physiology the models to which psychiatry should aspire. Edsall's memorandum had, after all, emphasised the need to develop "real scientific studies of psychiatric problems". ${ }^{1}$

\footnotetext{
${ }^{43}$ Staff Conference documents, 7 October 1930, RG 3, series 906, folder 17, box 2, RFA, RAC.

44 'What is psychiatry?' by Alan Gregg, 3 December 1941, RG 3, series 906, folder 19, box 2, RFA, RAC.

${ }^{45}$ Rockefeller Foundation Annual Report 1934, New York, p. 79.

${ }^{46}$ Ibid., pp. 111-13.

${ }^{47}$ In 1935 , the Division allocated $\$ 2,733,050$ for medical sciences, of which $\$ 1,459,450$ went to psychiatry (Rockefeller Foundation Annual Report 1935, New York, p. 69). In 1936, the total for the medical sciences was $\$ 1,623,750$, of which $\$ 702,050$ went to "psychiatry and allied subjects", $\$ 112,000$ to public health and preventive medicine teaching, and the rest to fellowships and small grants in aid (Rockefeller Foundation Annual Report 1936, New York, p. 133). In 1937, the Medical Sciences spent $\$ 2,392,100$ of which $\$ 1,392,100$ went to psychiatry (Rockefeller Foundation Annual Report 1937, New York, pp. 132-3). In 1938, psychiatry and allied fields received $\$ 873,300$ out of the $\$ 5,344,700$ spent by the Medical Sciences (Rockefeller Foundation Annual Report 1938, New York, p. 154). In 1939, the Medical Sciences allocated $\$ 1,927,180$, with psychiatry, neurology and allied fields getting $\$ 699,330$ (Rockefeller Foundation Annual Report 1939, New York, p. 160).

${ }^{48}$ Excerpt from the Medical Sciences Director's Report on the Program in Psychiatry, 11 December 1935, RG 3, series 906, folder 19, box 2, RFA, RAC.

${ }^{49}$ Excerpt from Staff Conference, 7 October 1930, RG 3, series 906, folder 17, box 2.

${ }^{50}$ Rockefeller Foundation Annual Report 1936, New York, p. 24.

51 David Edșall, 'Memorandum regarding possible psychiatric developments', 3 October 1930, RG 3, series 906 , folder 19, box 2, RFA, RAC.
} 


\section{Defining Psychiatry}

\section{Alan Gregg and the Definition of Psychiatry}

Alan Gregg was in control of a huge financial resource for the development of psychiatry; through his choices, the Rockefeller Foundation was contributing to the shaping of the field of psychiatry and defining what to exclude and what to include. Gregg's role and certain aspects of his biography and career encourage a portrayal of him as an enthusiastic champion of Meyer's psychobiology, of an all-embracing philosophy of mental illness, of an eclectic therapeutic and clinical approach and of Freudian psychoanalysis and psychoanalytically-infused psychosomatic medicine. ${ }^{52}$ Thus, Pressman writes of "Gregg's plan to remake psychiatry through a commitment to a program of psychobiology", claiming that Gregg refabricated "Meyer's doctrine of psychobiology in such a way that the laboratory was given center stage, resulting in a new framework that he made famous in America as psychosomatic medicine". ${ }^{53}$ While it is true that Gregg directed an ultimately quite visionary programme in psychiatry and was keenly influenced by Meyer's psychobiology, these statements of a straightforwardly positive commitment to a particular kind of psychiatry obscure his uncertainty, throughout his career, about the domain of psychiatry. Brown may be right that the philanthropy of a large foundation crystallised a movement towards a notion of psychosomatic medicine, ${ }^{54}$ but this emphasis threatens to underplay the difficulties of delimiting the boundaries of psychiatry and attempting to resolve fundamental questions about its nature.

Gregg had become interested in psychology and psychoanalysis while at Harvard..$^{55}$ At the Boston Psychopathic Hospital during the clinical years of his medical training, he became increasingly focused on physiology and infused with the scientific ideals dominating there. He then won a place at Massachusetts General Hospital, working in the highly physiologically and biochemically oriented scientific medicine recently introduced by David Edsall, Harvard's Jackson professor of medicine since 1912. Gregg's diaries at this time reveal that he was unsure about the adequacy of science as the sole basis for the practice of medicine ${ }^{56}$ Gregg started working at the Rockefeller Foundation in 1919, and in 1922 Richard Pearce offered him a job as his assistant in the Division of Medical Education (created in 1919). Pearce had trained under Simon Flexner (who became director of the Rockefeller Institute for Medical Research in 1902) and had worked with Edsall in the struggle for "scientific medicine" at Pennsylvania University. Pearce, when Gregg joined him, organised the Division in line with the expectations of Flexner, who was highly sceptical about psychiatry. In 1924 Gregg became associate director of Medical Education in charge of European operations; his work embodied Pearce's concerns with science and rigorous experimentation

\footnotetext{
${ }^{52}$ For accounts which tend to endorse this view, see Pressman, op. cit., note 32 above; Brown, op. cit., note 32 above; and Theodore M Brown, 'The rise and fall of psychosomatic medicine', read at the New York Academy of Medicine 29 November 2000, also published online in Human Nature, 8 November 2001, which tends slightly this way, although to a much lesser extent. See note 85 below.

${ }^{53}$ Pressman, op. cit., note 32 above, p. 33, italics in original.

${ }^{54}$ Brown, op. cit., note 52 above.

55 The following account of Gregg's life is derived from Wilder Penfield, The difficult art of giving: the epic of Alan Gregg, Boston, Little Brown, 1967; Brown, op. cit., note 32 above; and 'The reminiscences of Alan Gregg', a partial oral history memoir prepared by Dr Saul Benison for the Columbia Oral History Research Office, cited in Brown, op. cit., p. 157.

${ }^{56}$ Penfield, op. cit., note 55 above, p. 95.
} 


\section{Katherine Angel}

in medical research, and he expressed little interest in psychiatry or nervous and mental diseases. From the mid-twenties onwards, when the importance of psychiatry was becoming increasingly acknowledged, the Division of Medical Education began to encourage a predominantly biological approach to psychiatry - although at this time Gregg began to rediscover his interest in psychoanalysis.

After becoming director upon Pearce's death, Gregg succeeded, a few years later, in persuading the Foundation of the validity of the newly-proposed psychiatry programme. But behind the confident rhetoric concerning psychiatry in Gregg's and the Foundation's official publications and correspondence with outsiders, internal correspondence points to a considerable confusion as to what psychiatry included and excluded - a confusion which sat alongside an insistence on a psychiatry akin to scientific medicine. Thus in 1935; when the Foundation's psychiatry programme was well under way, Gregg reported at a staff conference "Kappel's suggestion that several organizations in and around New York interested in mental hygiene hold a conference for mutual information". 57 And as late as 1940, Raymond Fosdick (President of the Foundation from 1936 to 1948) wrote to Gregg that he had lunched with "Walter Steward, and he said he thought the lay members of the Board of Trustees didn't really understand what psychiatry was. He said he thought that some of them, at least, confused it with psychoanalysis, and thought it was primarily concerned with Freud and Jung. ... His suggestion was that at some future Board meeting ... you take half an hour to explain what modern psychiatry means and what you are trying to do with your program". 58

\section{The Chicago Institute for Psychoanalysis}

Gregg's involvement with the Chicago Institute for Psychoanalysis, set up in 1932 and headed by Franz Alexander, ${ }^{59}$ is sometimes invoked as an example of his own personal commitment to a vision of psychiatry that is Meyerian in its breadth, as well as to psychoanalysis in particular (about which Meyer himself had reservations). ${ }^{60}$ Thus Pressman writes that "Gregg underwrote the cost of one of the first psychoanalytic training institutes in America precisely because its director aggressively promoted a distinct psychosomatic orientation". ${ }^{61}$ Several Rockefeller sources reveal, however, that Gregg experienced considerable doubts about the merits of the Institute and increasingly of psychoanalysis.

In the early years of the psychiatry programme, the Foundation excluded psychoanalysis as a potential recipient of funding; ${ }^{62}$ a staff conference document in 1930 stated that "psychoanalysis is in a stage of development where it cannot be attacked philosophically and can be left to its own devices - it does not need money but needs

\footnotetext{
${ }^{57}$ Staff Conference, 14 November 1935, RG 3, series 906, folder 18, box 2, RFA, RAC. (Italics added.)

${ }^{58}$ Fosdick to Gregg, 28 November 1940, RG 3, series 906, folder 18, box 2, RFA, RAC.

${ }^{59}$ Franz Alexander (1891-1964) was a Hungarian who, after studying physiology, became a leading European analyst, moving to Chicago in the early 1930s. He developed psychoanalytic theories of somatic and psychological disorders.

${ }^{60}$ See Pressman, op. cit., note 32 above.

${ }^{61}$ Ibid, p. 35.

${ }^{62}$ See the annual reports of the Foundation in the early 1930 s.
} 


\section{Defining Psychiatry}

maturity and needs defeat in places where it does not stand up". ${ }^{63}$ Gregg rejected the Chicago Institute's initial overtures regarding funding on the grounds that it was a nonuniversity institute, while Chicago University still had no department of psychiatry. ${ }^{64}$ He was, however, willing, to correspond with and visit the Institute.

Dr Daniel O'Brien, assistant director of the Medical Sciences Division who advised Lewis prior to his trip, was not very impressed with the Institute or its doctors in 1933. He did not feel that they were "exceptional investigators or were presenting original ideas". ${ }^{65}$ O'Brien's tone is more dismissive than that of Gregg, who, in the same year, was "interested in the future of the Institute but did not think that this was the time for any action by the RF", 66 and who, according to Alfred K Stern (President of the Chicago Institute), had "recommended analysis to young psychiatrists in several cases". ${ }^{67}$ But Gregg was very cautious, and quick to quell the enthusiasm Stern sometimes misleadingly attributed to him while corresponding with Institute figures. ${ }^{68}$ Gregg thought that the Institute's members had "plenty of winnowing to do before they know enough to have something definitely to contribute to the study of somatic diseases"; he also stated that he had not "yet seen included what makes the simplest and to me the best case for psychoanalysis". 69

In 1935 , however, a grant of $\$ 100,000$ for three years was awarded to the Chicago Institute. The rationale was that "[p]sychoanalysis occupies an important part of the training of psychiatrists and is under present conditions costly and unsatisfactory, partly due to the fact that it is on a non-institutional basis". The Institute trained only medically qualified individuals, and emphasised the "correlation of medical and physiological problems with the findings of psychoanalysis". The aid would "afford an opportunity to psychoanalysis" and "protect and foster its relationship to medicine and psychiatry" ${ }^{70}$ Though "handicapped by the enthusiasms of some of its extreme adherents and the excited resentment of its opponents", psychoanalysis "deserves a fair opportunity to prove its ability and to be stripped of its false or useless phases". ${ }^{71}$ Testing psychoanalysis in an institution "would favour comparison, exchange of opinion, verification and a correlation with the findings of internal medicine, surgery and the more orthodox views of psychiatry". ${ }^{72}$ Funding would thus temper the unscientific

${ }^{63}$ Excerpt from Staff Conference, 7 October 1930, RG 3, series 906, folder 17, box 2, RFA, RAC. See also Edsall's 'Memorandum regarding possible psychiatric developments', cited in note 38 above.

${ }^{64}$ Alan Gregg officer's diary, 4 April 1932, RG 12.1, RFA, RAC.

${ }^{65}$ Daniel P O'Brien officer's diary, 13 January 1933, RG 12.1, RFA, RAC.

${ }^{66}$ Alan Gregg officer's diary, 18 May 1933, RG 12.1, RFA, RAC.

${ }^{67}$ Stern to Gregg, 2 June 1933, RG 1.1, series 216A, folder 26, box 3, RFA, RAC.

${ }^{68}$ Stern forwarded to Gregg a document for the Board of Trustees at the Chicago Institute; in it Stern claimed that the Foundation was ready to consider fellowships for exceptional candidates and that if after a few years, "when subscriptions were no longer adequate to carry on the Institute's program and a university has not yet taken over the Institute, [Gregg] would be willing to recommend a direct appropriation from the RF." Next to this Gregg wrote in the column of his copy: "Conditions may change so that I would not be willing to do this." Moreover, he requested Stern not to send this document to his Trustees; Gregg would himself make a statement on his position. Stern to Gregg, 2 June 1933, RG 1.1, series 216A, folder 26, box 3, RFA, RAC.

${ }^{69}$ Alan Gregg officer's diary, 14 February 1933, RG 12.1, RFA, RAC.

70 'Program in Medical Sciences', June 1935, RG 1.1, series 216A, folder 25, box 3, RFA, RAC.

71 'Program in Medical Sciences' 3 April 1935, RG 1.1, series 216A, folder 28, box 3, RFA, RAC.

${ }^{72}$ Ibid. 


\section{Katherine Angel}

tendencies of psychoanalysis and bring it under the control of a scientific psychiatry. The Foundation's involvement was generous, but controlling; support and supervision went hand in hand, in the hope that the Rockefeller could help shape the Institute's activities and encourage the shedding of any speculative elements. ${ }^{73}$

The Chicago Institute was the only such institution funded by the Rockefeller at the time. ${ }^{74}$ The annual report of 1935 shows that the bulk of funds for the development of teaching and research went largely to subjects such as genetics, obstetrics and gynaecology, surgery, dementia praecox, neuroanatomy, experimental neurology, physiological optics, reflex behaviour, living tissue growth, and infantile paralysis. ${ }^{75}$ (These same priorities are evident in the annual reports of the following years.) Fosdick, giving an overview of Gregg's psychiatry programme, lists brain chemistry, epilepsy, neurophysiology, carbohydrate metabolism, schizophrenia, genetic factors in mental and nervous disease and heredity as the subjects given grants. ${ }^{76}$ While some of these projects may have incorporated psychoanalytic, psychosomatic or psychodynamic elements, claims that the Rockefeller's programme derived from a positive vision of psychiatry as all-embracing, environment-focused and psychosomatic, seem misrepresentative. ${ }^{77}$

By 1937, Gregg indicated that, despite progress in teaching, there were problems emerging with the Chicago Institute. There would "probably not be a case for further RF aid beyond a three-to-five year period beyond 1937", and any action taken by the RF "must be made with a clear understanding of termination at the end of the period". 78 Gregg and his colleagues became irritable and exasperated with Alexander and Stern, ${ }^{79}$ experiencing difficulties in persuading Alexander to steer clear of speculative work and focus on sound experimental work on psychogenic and somatic factors. In 1939, R A Lambert, associate director of the Medical Sciences Division, while discussing a

\footnotetext{
${ }^{73}$ Gregg also employed this strategy with Stanley Cobb's psychoanalytic projects at Massachusetts General. See Brown, op. cit., note 52 above.

${ }^{74}$ Brown writes that Alexander was the only psychoanalyst to receive large direct grants from the Rockefeller Foundation; Brown, op. cit., note 52 above. The Division later funded, however, psychoanalytic projects at Massachusetts General, Cornell Medical School and Washington University, and, after the war, Gregg tried to help the Tavistock Clinic obtain university recognition. See note 85 below.

${ }^{75}$ Rockefeller Foundation Annual Report 1935, New York, pp. 69-117. Of 25 grants-in-aid paid to American physician post-doctoral students, 8 went to psychiatry, 4 to neuropathology, 4 to neurophysiology, 3 to neurology, 2 each to advanced psychiatry and neuroanatomy, and 1 each to clinical psychiatry, public health administration, neurosurgery, psychoanalysis, endocrinology, biochemistry and educational psychology. Ibid, p. 98.

${ }^{76}$ Fosdick, op. cit., note 10 above, p. 150.

${ }^{77}$ While Brown tends to argue this view (see op. cit., note 52 above), he also captures the overall philosophy of Gregg's programme by describing it as an "interdisciplinary amalgam" in neuropsychiatry "dominated by the biological sciences but interspersed with psychoanalysis". Brown, op. cit., note 32 above, p. 167.

${ }^{78}$ Alan Gregg officer's diary, 2 November 1937, RG 12.1, RFA, RAC.

${ }^{79}$ Gregg recommended to Alexander and Stern that they "avoid getting a martyr complex on the subject of the position of psychoanalysis in medicine", and that they should avoid alienating the sympathies of interested observers with "flare-ups of ambition". (Alan Gregg officer's diary, 8 February 1934, RG 12.1, RFA, RAC). He repeatedly stalled the ambition of Alexander, for example over the project for a Journal of Psychosomatic Medicine. (Alan Gregg officer's diary, 15 October 1935, RG 12.1, RFA, RAC.) And Alexander and Stern made requests Gregg and his colleagues found presumptuous; after Stern wrote to Max Mason in 1934 (President of the Rockefeller 1929-1936 and Director of the Natural Sciences Division 1928-9) about an apparent pledge of $\$ 20,000$ a year, Mason wrote in the column: "Too strong by $1000 \%$. I said I would mention their present need to AG, but Stern knew our attitude, which was highly conservative". Stern to Mason, 1 February 1934, RG 1.1, series 216 A, folder 21, box 3, RFA, RAC.
} 


\section{Defining Psychiatry}

possible appointment at the Institute, wondered whether an applicant is "just a pseudoscientist, as most others in his field", adding, "I still don't think much of the Chicago Institute crowd. Maybe Alexander has contributed a little something towards making psychoanalysis respectable, but he certainly has not brought it into the scientific fold. I shall feel a relief when the RF grant terminates - and is not renewed" ${ }^{80}$ In his reply, O'Brien concurred. ${ }^{81}$ While these men may have been more hostile than Gregg to the Institute, the latter nevertheless recorded that "the lack of the service of a firstrate physiologist with the equipment of a physiological lab" constituted a "defect in realizing the present program of the Institute and its investigations of psychosomatic medicine". ${ }^{2}$ Pressman's statement (see page 50 above) regarding the rationale for Gregg's funding of the Chicago Institute can now be seen as misleading, obscuring as it does Gregg's constant and increasing uncertainty as to the merits of the institution.

Gregg's psychiatry programme had to be seen to address satisfactorily worries over any projects whose scientific status was questionable. The Chicago Institute was the main project risking criticism on this front, and it was not entirely successful ${ }^{83}$ In Gregg's career - which saw a move from a straightforward enthusiasm for psychoanalysis to an endorsement of the merits of a scientific approach - his position at the Rockefeller involved a concrete attempt to define the boundaries of psychiatry; that is, to answer a pressing philosophical question about the nature of the scientific study of the mind. The success - in his view and the Rockefeller's - of the decisions he would take over whom to fund would no doubt have represented to Gregg the extent of the judiciousness of his answer to this question, and that of his own professional and personal choices.

Gregg was not, then, a lone pioneer seeking to convince sceptics; he was sympathetic to psychoanalysis and psychosomatic medicine, but he favoured an interdisciplinary matrix dominated by experimentally grounded sciences. Gregg was operating within a hugely powerful institution with a robust ideology about its role within the development of science and about the methods of science. It was trying to work out just how psychiatry fitted into this scheme. As psychiatry grew into a medical specialty it would have to commit to certain criteria of medical science, such as the importance of controlled experiments, rather than the judgement of individual clinicians. While the Rockefeller helped to establish a field where clinical and research opportunities were significantly widened and the boundaries between self and society were increasingly dissolved, medicalising psychiatry presented difficult challenges. Pressman, writing about the pressures that emerged once this movement was well under way and achieving some success, notes that in order for a unified professional and disciplinary identity to be forged, notions of what constituted valid scientific and medical knowledge had

${ }^{80}$ Lambert to O'Brien, 22 August 1939, RG 1.1, series 216 A, folder 37, box 3, RFA, RAC.

${ }^{81}$ O'Brien to Lambert, 30 August 1939, RG 1.1, series 216 A, folder 37, box 3, RFA, RAC.

${ }^{82}$ Alan Gregg officer's diary, 18 September 1939, RG 12.1, RFA, RAC.

${ }^{83} \mathrm{Gregg}$ was involved in other, more rigorous and fruitful, experimental work being conducted on psychosomatic interactions by Stanley Cobb's department at Massachusetts General and by Harold Wolff at Cornell Medical Center. In 1938 Gregg launched a new, and ultimately more successful, project at Washington University in St Louis, with the aim of bringing together neurological, psychiatric and psychoanalytic elements. By this time psychoanalysis was slowly gaining an increasing presence in university psychiatric departments, and the enterprise may not have been so much of a risk, partly due to the nature of this later work and also to the length of time the psychiatry programme had been running. 


\section{Katherine Angel}

to be large enough to allow diverse groups to work together under the same banner, and that this created anxiety amongst established scientists by potentially enabling non-medically trained professionals to encroach on the field and dilute the scientific credentials of a hard-won respectability. ${ }^{84}$ But he omits the significance of this anxiety about the boundaries of psychiatry at the outset of the field's consolidation ${ }^{85}-$ an anxiety that was clearly besetting both the Rockefeller as a whole and Gregg in particular, shaping the lens through which they perceived institutions and projects and thus their choices of which to fund and develop.

\section{The Rockefeller and Aubrey Lewis}

The Rockefeller was initially hesitant when approached by Mapother for funding of the Maudsley; its concerns were not so much with any particular activity of the hospital, but rather with the general backwardness of (scientific) psychiatry in England ${ }^{86}$ Lambert commented, "there are not enough scientific papers being turned out in England to fill one small journal whereas lesser countries like Belgium and Italy support several such journals of comparable quality.... Outside London there is hardly a place where any research in psychiatry is being done.... I feel a little disappointed myself at the Maudsley show. The laboratory facilities are limited, and there is hardly any provision for animal experimentation". 87

These concerns may go some way towards explaining the Foundation's caution regarding the Maudsley, although the reason given for holding back was the economic crisis facing the US. ${ }^{88}$ Its initial decision to fund training fellowships would support this, especially as the influx of German émigrés after 1933 provided an opportunity, as Mapother himself phrased it, "of securing a bargain group of first-rate men" ${ }^{89}$ The presence of German scientists was felt to have injected valuable scientific work and methods to the hospital, encouraging the Rockefeller Foundation to consider more substantial funding. ${ }^{90}$ More funding from the Rockefeller Foundation would depend

${ }^{84}$ Pressman, op. cit., note 32 above, pp. 41-6.

${ }^{85}$ Although Brown gives a detailed account of the increasing scepticism Gregg experienced with respect to the Chicago Institute, he too somewhat obscures both Gregg's worries at the inception of the psychiatry programme and in the early stages of the Chicago project. (Brown op. cit., note 32 above, pp. 167-82, and idem, op. cit., note 52 above.)

86 "Eventually, even if successful, the program will not involve anything like half of what Mapother is now visualising", from Staff Conference, 16 March 1931, RG 1.1, series 401A, folder 247, box 18, RFA, RAC.

${ }^{87}$ R A Lambert officer's diary, 5 December 1933, RG 1.1, series 401A, folder 248, box 18, RFA, RAC. It is interesting that in the report Lewis notes (p. 99) that although there is a proliferation of Italian research literature in journals, the standard is quite low.

${ }^{88}$ Gregg to Mapother, 11 December 1931, series 401A, folder 247, box 18, RFA, RAC. Also Gregg to Mapother, 31 May 1932, RG 1.1, series 401A, folder 248, box 18.

${ }^{89}$ R A Lambert officer's diary, 5 December 1933, RG 1.1, series 401A, folder 248, box 18, RFA, RAC.

${ }^{90}$ Gregg to Mapother, 21 December 1933, RG 1.1, series 401A, folder 248, box 18, RFA, RAC. O'Brien writes that the "scheme for aid at the Maudsley is to benefit by the presence of the deposed Germans there". O'Brien to Gregg, 5 November 1934, RG 1.1, series 401A, box 19, folder 250, RFA, RAC. In Lambert's view "[it] is clear that psychiatry in England needs a real center of research, and that an opportunity for setting up such a center presents itself at the Maudsley through the fortuitous presence of an exceptionally able group of German workers. ... It might be hoped that in a year or two a supply of British [sic] might be coming on to take the places of foreigners who drop out for one reason or another. The reason for using foreigners now is simply that there are practically no natives of equal calibre to be had." Lambert to O'Brien, 8 January 1935, RG 1.1, series 401A, folder 251, box 19, RFA, RAC. 


\section{Defining Psychiatry}

on its perceiving the Maudsley as pursuing a scientific orientation, and having the resources and personnel to do this. The Maudsley's long-term status would be best fostered by British workers themselves steeped in expertise of the kind the German émigrés had brought; and thus Lewis's trip can be seen as a step towards this end.

The report, however, can also be seen as one element in a wider dialogue during the 1930s concerning the definition of psychiatry and as part of the dynamics between philanthropic foundation and possible beneficiary. One of the report's most interesting features is the extent to which it is shaped by the Rockefeller and mirrors its concerns and attitudes. Lewis met and exchanged letters with Daniel O'Brien, Alan Gregg's deputy, who sent him a list of key people to meet - which Lewis pretty much adhered to - as well as letters of introduction. O'Brien's list favoured highly experimental, physiological and laboratory-based workers and institutes; writing about Vienna he noted - briefly and possibly dismissively - the "Freudian group (Herr Geheimrat and daughter Anna)", who "hardly need be mentioned", as well as the Bühlers, but emphasised physiological and scientific figures. ${ }^{91}$ In his introduction, Lewis describes psychiatry as an enormous field straddling innumerable disciplines and activities and urges collaboration amongst these $;{ }^{92}$ in his concluding comments he notes that "almost everywhere I found a greater interest and activity on the physical than on the psychological or sociological side of psychiatric inquiry" and that psychological investigations tended to "follow safe rather than speculative lines", 93 suggesting that the dominance of "physical" psychiatry represented in his report is to some extent just a feature of the field. His attitude, however, echoes O'Brien's; he is sceptical of individuals with psychoanalytic backgrounds and interests, being pleasantly surprised when they reveal scientific knowledge and common sense; ${ }^{94}$ he gives the Freudians short shrift while in Vienna; and consistently displays irritation with "speculative" developments and a preference for elements representative of a scientific and medical psychiatry. What is evident throughout the report is his concern with clarifying the boundaries of psychiatry; ${ }^{95}$ with the dispassionate study of psychotherapy's merits; ${ }^{96}$ and with the pruning of extravagances which "delay the development of the social and psychological side of psychiatry". ${ }^{7}$

Both Mapother and Lewis considered scrupulous fact-gathering and rigorous quantitative evaluation methods crucial to grounding psychiatry as a reputable branch of medicine. Mapother favoured neurology as psychiatry's ideal partner and both urged experiment as the means to determine therapeutic efficacy. The individual may be a psychobiological entity to be approached with a range of methods, but the scientific nature of these methods would determine the discipline's legitimacy. Both Lewis and Mapother would have keenly felt the need to continue courting the Rockefeller Foundation in order to prolong and enlarge its funding of the Maudsley, and the funding

\footnotetext{
${ }^{91}$ Letter from D P O'Brien to Aubrey Lewis, 23 February 1937, p. 6; held by the Lewis family.

92 Introduction to the Report, pp. 57-9.

${ }^{93}$ Report, p. 146.

${ }^{94}$ For example: "Lagache is a Freudian, but fairly well equipped also on the somatic side", Report, p. 81.

${ }^{95}$ For example, Introduction to the Report, p. 59.

${ }^{96}$ Introduction to the Report, p. 60.

${ }^{97}$ Introduction to the Report, p. 60.
} 


\section{Katherine Angel}

question was inextricably linked to the question of the nature and status of psychiatry. What Lewis's report very neatly reflects is a discipline in flux, whose membership was being worked out, both by psychiatrists and by the Foundation, in a way that would shape the field's development. It was lucky that Lewis, a notoriously frank man (who indeed risked coming across as arrogant and dismissive in his criticisms of continental psychiatry) shared the Foundation's fundamental orientation and scepticism over certain branches of the field. His report, which endorses an ideal held by the Rockefeller and Alan Gregg in particular - the ideal of science as a criterion to weed out speculative and descriptive elements - was one factor in a protracted negotiation between benefactor and beneficiary that could ultimately only bear fruit given a shared vision of psychiatry. The Maudsley-Rockefeller marriage was a relatively happy one, with both parties longing to delineate - as Mapother put it - "the objective facts of psychiatry omitting the spookery". 98

${ }^{98}$ Mapother to Gregg, 12 December 1936, RG 1.1, folder 253, box 19, series 401 A, RFA, RAC. 